\title{
From Malaise to Welfare in Teaching: Elements for Teachers Education
}

\section{Aline Rocha Mendes ${ }^{1}$, Karina Pacheco Dohms' ${ }^{1}$, Saul Neves de Jesus ${ }^{2}$, Bettina Steren dos Santos ${ }^{1}$, Claus Dieter Stobäus ${ }^{3}$, Juan José Mouriño Mosquera ${ }^{4}$}

\author{
${ }^{1}$ Postgraduate Programs in Education, Pontifical Chatolic University of Rio Grande do Sul, Porto Alegre, RS, Brazil \\ ${ }^{2}$ Postgraduate Program of Psychology, University of Algarve, Faro, Portugal \\ ${ }^{3}$ Postgraduate Programs in Education and in Biomedical Gerontology, Pontifical Chatolic University of Rio Grande do Sul, Porto \\ Alegre, RS, Brazil \\ ${ }^{4}$ Postgraduate Program in Education, Pro-Rectory of Postgraduate and Research, Pontifical Chatolic University of Rio Grande do \\ Sul, Porto Alegre, RS, Brazil \\ Email: stobaus@pucrs.br
}

How to cite this paper: Mendes, A. R. Dohms, K. P., de Jesus, S. N., dos Santos, B. S., Stobäus, C. D., \& Mosquera, J. J. M. (2017) From Malaise to Welfare in Teaching: Elements for Teachers Education. Creative Education, 8, 1193-1212.

https://doi.org/10.4236/ce.2017.88085

Received: March 31, 2017

Accepted: July 2, 2017

Published: July 5, 2017

Copyright () 2017 by authors and Scientific Research Publishing Inc. This work is licensed under the Creative Commons Attribution International License (CC BY 4.0).

http://creativecommons.org/licenses/by/4.0/

\begin{abstract}
The article gives elements and also goes forward on understanding the presence of teachers' malaise and/or welfare in the education field, influencing teachers as professional and as person, and reporting research results and reflections based on literature. It also pointed some directions to relations with Psychology, Special/Inclusive Education, and use of the Information and Communication Technologies, linked to Positive Psychology and Health Psychology.
\end{abstract}

\section{Keywords}

Teachers Malaise, Teachers Welfare, Wellbeing, Teachers Education

\section{Introduction}

To address the issue Malaise in Teaching, we cannot forget the historical moments, political and personal experiences because they can provide further explanation of dynamics and possible causes and consequences of this malaise. We are living in a moment in which the school is still widely criticized. Researchers, among which we highlight Esteve (1984, 1994, 2005) and Abraham et al. (1986), were trying to understand the topic and present data showing the difficulties encountered in schools in an attempt to help rediscover their role in contemporary society.

No doubt there are crises in school while their function, the pedagogical actions, influenced by rapid changes in the social context, the introduction of in- 
creasingly innovative computer tools to disseminate information on other faster means greater coverage and that very school, such as the Internet. We are moving from a linear to an interactive and systemic system of knowledge transmission with consequent changes in the forms of teaching and learning system. We as educators are concerned with this new reality, we must update us, for example, by studying some of the reasons why these crises, in order to propose some ways that may help to understand and perhaps help reverse this frame. We know from economic, political, social, occupational causes, but almost nothing is pointed in the person of the teacher, their concerns, interests, feelings, values and expectations.

Esteve (1994) indicates to several factors that cause teachers discomfort such as lack of time, numerous classes, paperwork, and disbelief in teaching, among others. Besides these reasons, we think it is important to pay special attention to the discomfort caused by the introduction of Information Technology and Communication in educational institutions.

The teaching was considered one of the most respected sources of knowledge, however, with the decentralization and democratization of knowledge. That status is in jeopardy, thus becoming more of a factor that promotes the teacher malaise.

New socialization agents arrived on the scene, and teachers should have a professional qualification that accompanies this change. Years ago a teacher was almost solely responsible for the transmission of information and culture, today we can say that this situation is modified by technological advances developed by mankind. Teachers who do not take this issue into account are likely to fail in their task, adding to the malaise previously mentioned.

Thinking on this matter is that we, for some time (1996) now, studying how teachers described working in schools, as reported on the relationship with their peers, from data collected at several universities. In previous research (Mosquera \& Stobäus, 2003) we expand on these aspects. Also Esteve $(1984,1994)$ and de Jesus (1997) iniciate researchs results on these time.

We consider it important to deepen from the reality evidenced in teachers education, specially in our context at PUCRS, in Porto Alegre-RS, since 2000, when we propose to study this question in different contextual realities. Already knowing the different realities/contexts, in our state/country, through the pronouncements of some of teachers (e.g. Pontifical Catholic University of Rio Grande do Sul, Federal University of Rio Grande do Sul, Federal University of Santa Maria, University of Santa Cruz do Sul, all in Rio Grande do Sul StateSouth of Brazil), we found information that can be used to assist in overcoming personal and professional "crises", that are occurring with these teachers, and can propose some changes for aid them and their institutions. With these elements, we can also aid in the construction for understand the distinct realities and project new possibilities, extending to other countries in other countries.

So, we report quantitative, qualitative, and mixed surveys of teacher education, especially relating to Portuguese studies.

\section{Malaise Aspects in Teaching}

The problems besetting the teaching profession are not new, nor original; find 
themselves connected to the source itself, the historical development and the social value of this profession. What is most impressive is the continued worsening of the problem in almost all the world and that, as the social fabric, teaching is greatly eroded before the justified grievances of teachers, students' grievances, the poorness of knowledge (called the poor quality in Education) and distrust in social exploitation, and elements related to learning and their disturbances. Although Mosquera (1978) have been concerned about this topic since 1975, and realize that it seems relegated to the background because what people are really does not appear as important as the people they represent.

We must remember that the dynamics and signification of malaise were raised by Freud (1974: 43), when he said:

We have given response by indicating that the three sources of our suffering comes from: the superior power of nature, the fragility of our own bodies and the inadequacy of rules that seek to adjust the mutual relationships of human beings in the family, the State and Society.

This thinking demonstrates that the complexity of human existence cannot be naively reduced to a simple explanation and limiting. It is clear that some explanations, at times, are more appropriate than others and obviously have more timely dialectic and conviction.

A fairly large group of researchers, worldwide, has been concerned by the burning issues like personality of the teachers, their disillusionment, their diseases, poor quality of teaching and the questionable role of educational institutions, both official and private.

Among them are Esteve $(1984,1994)$, with which we contact the Universidad de Málaga-Spain, also de Jesus (1996, 1997, 1998a, 1998b, 1999), who studied the themes of malaise and welfare/wellbeing in Heath and Education. Also Sousa (2006), with studies about resilience, and other peers with whom we are collaborating and performing constant academic exchanges, through the agreement with PUCRS maintained by the University of Algarve, Faro, Portugal.

Abraham et al. (1986) works with the theme, from the University of Jerusalem. We must remember that the concern is international and not only restricted to Third World countries.

Esteve $(1984,1994,2005)$ notes that the topic teacher malaise is being used in psychoeducational literature for a long time, to describe the permanent effects of negative character that affect the personality of the teacher, as a result of the psychological and social conditions that are exercised in teaching and contributing to it. Indeed, he speaks about the conjunction of several misdiagnosed social and psychological factors are producing what we shall call a degenerative cycle of teacher effectiveness. This idea is quite significant because it expresses something that is present among us: just examine the climates of hate and unnecessary, frequent competition in educational centers.

Esteve (1984) believe that improving education mainly depends on the recognition of the work and the profession itself. Therefore, we can say that the teachers discomfort is social disease that can causes personal and can be caused 
by a lack of social support for teachers, both in the field of teaching objectives, as in material compensation and recognition of that status if they assigns.

In reality, the economic and political conditions have not been sufficiently favorable to teachers: teachers seem to be doomed to evil conduct their work, since the charges are rampant.

As said Esteve (1984, 1994), among the causes of teacher malaise we may note, which is already found in these studies at the international level as well as in our studies in Brazil, but also in other parts of the world: -Lack of enough time to do a decent job if the added difficulties students and increasingly numerous classes; -Paperwork that steals time from the main task is teaching and is the fatigue factor; -Disbelief in teaching and basic modifications of student learning factor; and -Changes in knowledge and social innovations and challenges that cause great anxiety and feelings of worthlessness.

Some of these causes have deep roots, which can be located on disability: positions and plans of the State Government as triggers of a truly effective education; lack of a philosophy of education known to all and everyone worked, analyzed, discussed and negotiated; believe that one of the great chaos of Education is the lack of solid philosophical principles that are expressed in an image of human being and especially an open, consistent and mainly democratic educational purposes; the need for education for citizenship, in which human rights and attitudes of tolerance can be exchanged; and lack of central importance in considering the issues of means and resources of Education, which express the commitment of the entire social and signify the dignified permanence of teaching as real work and critical profession. Failure to consider knowledge as a real value that provides tools for the changes in a world where there is poverty, ignorance and unawareness.

Freire (1979) has been quite clear on this subject, which is quoted here by considering the revolutionary known as the best weapon that a human being possesses possibilitating changes with the education process.

\section{Specifying Malaise Indicators in Education}

The aspects discussed so far are quite large and problematic, which leads us to specify to better analyze.

Esteve $(1984,1994)$ notes that there are two types of factors that cause unease in teaching: the second and the first order.

\subsection{Second Order Factors}

1) Changes in the teacher's role and the traditional agents of socialization.

2) The teaching function: contestation and contradictions.

3) Modification of the support of the social context.

4) The objectives of the education system and the progress of knowledge.

5) The image of the teacher.

Evidently, these factors have wide repercussions for the behavior of teachers and their reality. Nobody can deny that traditional agents such as family have 
virtually abandoned their socializing functions, carrying educational institutions with more charges, which complicates the already difficult task of educating.

In turn, the teaching profession itself is contested externally and internally. We note that there is a progressive personal and collective disillusionment about education, emanating from not understanding the value of teaching and the consistent work performance of the teacher. The ideal image serves as a pretext to hide the real working image of the teacher and his subsequent performance.

Another contextual factor is distrust of teachers in society, with regard to commitment, efficiency and effectiveness. It is no doubt there are powerful reasons for this, but it is incomprehensible that no one understands that the unequal treatment labor wears any good intentions whatsoever.

Finally, the image of the teacher is a crisp image. Esteve (1984) warns that faculty conflicts are neither free nor capricious. There is a necessity to restore social and mainly psychological aspects of teaching.

\subsection{First Order Factors}

1) Material resources and working conditions.

2) Violence in schools.

3) Teaching Depletion and accumulation of demands on the teacher.

It is clear that these factors are splitting the previous ones, but they have quirks that are worth examining.

A deficiency of material resources and working conditions is well known, especially in developing countries, is a full meltdown. There is a lack of pedagogical and instrumental, in most cases, to the hygienic conditions are concerned. The question then is: how to do a competent job?

Violence in schools can be understood by latent or overt aggression inside and outside the classroom. By changing the hard line of teachers, coexistence is not always so peaceful with students. Cases of aggression are increasingly evident in both parties. Often appears disguised as symbolic, manifested by jokingly, sometimes ironic, and subjects are treated worse when they occur in interpersonal relationships.

Moreover, it is significant to note the power struggle. Perhaps the lack of a political education leads to confuse policy with partisan politics and have little tolerance of differences and different positions.

This is a topic still veiled, but it deserves study and consideration, because democracy is a negotiated social life, in which everyone has space. Is away from the threat of roasting, indoctrination and dogmatism? Remember that the ideas triumph for its own sake and not by fanaticism that we print them. The most worrying aspect is the depletion of the teacher (called the "burnt" teacher, burnout in English).

Another perspective in psychological aspects, toward psychological health: violent criticism on authorities (often justified). The exhaustion is a clear consequence of the teacher malaise that leads to discouragement, disillusionment and hopelessness, in direction of really sickness. 


\subsection{Relations between Technology, Education and Malaise/Wellbeing}

Another highlight is the fast and increasing technological advancement, which tends to replace, at least in some areas of knowledge, the traditional means of access and delivery of information. This was before unidirectional, such as radio and TV, and even the room more traditional classroom and teacher green and chalk board, passing technology to a convergent, that is, a computer/media that enables the combination of different forms of interacting, with as much information between people (hypertext, animation, sound, etc.). So, we went from close range for a wide range, with more information and greater speed, i.e., increased quantity and quality in the interaction of people with the information.

Is it the same in the school, are we prepared to these rapidly changes? As we described (Mosquera, Stobäus, \& Huertas, 2015), there are differences between the teachers in the preparation of the personal, professional and social components in the teachers training.

These changes cause greater interactivity between people and greater autonomy in the pursuit of knowledge, require more habilities/competences and can be related to malaise aspects.

Until the emergence of computer networks, communication technologies were divided into two categories: one-to-one and one-to-many (one-to-some). It is important to note that currently, the strengths of each of these categories abeam of Information and Communication Technologies can be combined. The Internet allows one type of interaction, many-to-many, where communication can be synchronous or asynchronous. One can say that an interaction via computer networks, presents three important aspects: the temporality (asynchronous and synchronous), direction (unilateral, bilateral and multilateral) and the number of interlocutors. This form of interaction promotes collective construction of knowledge, forming networks where information can be accessed easily. Thus constitutes currently Cyberspace, being increasingly incorporated into routines of everyday life, thus having the opportunity to build new kinds of communities (dos Santos, Stobäus, Mosquera, \& Missel, 2005).

Therefore, in the schools and the educational system, education professionals are faced with the task of putting up with this trend in a way that is educationally suitable, culturally intelligent and socially responsible.

The teacher should ask whether computer use is or is not contributing to the construction of new knowledge in the student. To be able to answer that question, the teacher must know the different ways of using computers in Education, programming, development, and multimedia and Internet use and understand the resources they provide for the construction of knowledge. When the teacher feel more familiar with the technical issues, can engage in the exploitation of more sophisticated information technology in learning activities. The teacher should challenge the student to know that from each proposed project, it can achieve pedagogical goals he set his plan.

If there is Distance Education, some technologies are "very new", and the 
preparation and continuous education of the teachers must be also collaborative, says Weber, Mosquera, \& Stobäus (2009).

Is forming a society in which the value of information will no longer be a value in itself to constitute itself as a value, as it is being used wisely. This high demand for good education gives the information and criteria, and can be transformed into authentic knowledge. For this transformation, there are new features that can help you promote it, the multimedia, as they integrate various languages-writing, sound, spelling.

\subsection{Teachers Malaise/Wellbeing in Inclusive Education}

In addition to technological aspects, another area in which malaise may be present is Special Education/Full Inclusion.

Grounding the topic in these area, we recall our study (Stobäus \& Mosquera, $2005,2012)$ in which we detected some of the points that we will deepen, especially the issue of lack of a better preparation of teachers in this area, in order better address some conflicts arising from the novelty is the inclusion, not the theoretical point of view, but rather to get a student teacher who has some difficulty connected with themes ranging from the gifted/high ability to the other extreme, students with special education needs, the most varied as dyscalculia, dyslexia, attention deficit/hyperactivity disorder, even well "below", including syndromic, mentally handicapped and other diseases with which it is called to act. This is reported by the interviewed teachers as causing great discomfort, lack of support and preparation specific swimsuits, and we seek elements that allow us to assist these teachers.

In the Special Education teachers, who bear a great burden, we can even put more specifically that the teacher can be an overload of having to deal with their own continuing education to pupils with special educational needs and, undoubtedly, their parents and/or other caregivers, who are in charge of all education aid to these students. We emphasize (Teixeira, Mosquera, \& Stobäus, 2015) it with the descriptions that these teachers gave us, telling about satisfactions, dissatisfactions and difficulties in their daily work.

Being, in fact, it is consence that the teacher is responsible directly of your work, so your need for supplementary and continuing education is paramount, but it does not always have the means and is serviced. Therefore, our research is of significance and importance, since it may provide this gap in their continuing education.

\subsection{Teachers Malaise/Welfare in Non-Formal Education}

In a broader sense, the malaise can also be detected in non-formal situations, such as would be in the education system, whether municipal, state or federal, the school formally constituted, or even the university, through its directors or teachers, and also their students. He is also in situations of non-formal education, as would courses, swimming schools, academies or language courses.

It is also worth remembering that in the fields of informal education such as 
trade unions, NGOs, the so-called Third Sector, very concerned about these climates that are established between people.

\section{Strategies to Promote Teacher Wellness}

As pointed out by de Jesus (1998a, 1998b, 1999, 2001), that teamwork is one of the strategies to promote teacher wellness and can be performed in a way that he feels in a situation of trimming and more comfortable, either as a psychodrama or in workshops for this purpose. Teachers learn a lot not only through his own experience, no doubt also to hold meetings of healthy experiences and can be individual or collective, where there are good relationships with colleagues, are topics of daily life, the possibilities of interdisciplinarity treated, always in order to decrease the discomfort and could promote strategies for better wellness through exchange with their peers, especially when there are relations with affectivity (Mosquera \& Stobäus, 2006) and self-care (Mosquera, Stobäus, \& Timm, 2009).

As evaluated in the research of de Jesus et al. (2011, 2012), there are similarities between the data obtained in Brasil and Portugal.

As explained de Jesus (2001), ways to manage stress can be greatly enhanced through measures such as:

-Elimination of the causes;

-Increasing resources;

-Rearrange the personal and professional life;

-Working with the mind, creating a positive image of themselves;

-Develop means of defense;

-Teamwork:

-Time management;

-Firmness in decisions;

-Leveraging communication;

-Adopting a healthy lifestyle;

-Caring for healthy eating;

-Making regular exercise;

-Occupy leisure; and

-Having relaxation.

These are all, of course there will be other, there can be proposed that teachers feel more participants in their relationships and better prepared for tackling efficiently and effectively, as highlighted Stobäus \& Mosquera (1984).

The Assessment Questionnaire of Teacher Malaise/Wellbeing of de Jesus (1996, 1998a), contains some of the elements that work in our workshops. Basically aims to address topics such as:

- Professional design and professional commitment;

- Value of professional goals;

- Intrinsic motivation;

- Expectancy and efficacy expectancy control;

- Stress and professional exhaustion; 
- Irrational beliefs;

- Coping strategies;

- Professional Success; and

- Initial motivation.

From this angle, we can see that there is, in particular, focused elements in extrinsic and intrinsic motivation, based on ideas proposed enough time by Maslow (sd, 1982, 2000), the author already quoted earlier there.

In another direction, we can also see researches, as cited by Sampaio, Stobäus, Mosquera, \& de Jesus (2012), who used workshops, based on the ideas of de Jesus (1997), to develop better relationships between the team of teachers and maintain the motivation for a good period of time. Pereira, de Jesus, Esteve, Lens, Mosquera, \& Stobäus (2002) described the results of longitudinal training programs for teachers well being.

About different teacher's motivations, there are good comments on dos Santos, \& Carreño (2010).

\section{Results of Our Research Group}

One of these researches (Mosquera \& Stobäus, 2003) was housed within the Research Line Person and Education, at our Graduate Education-PUCRS (Stobäus, Mosquera, \& dos Santos, 2007), with the collaboration of our colleagues and students, and our production is directly linked to these themes. We intent better understanding the teachers as professionals and especially as a developing person, in a positive climate (Stobäus \& Mosquera, 2014), in these moments, about how they think and how report their acts. To constitute a set of subsidies to be able to discuss and improve their training, both initial and continued in service, just within the suggested proposal and requested by their universities in that they participate, in the cities of Santa Maria, Santa Cruz do Sul, Canoas and Porto Alegre, State of Rio Grande do Sul-BR.

These researches have a qualitative approach, through case study, intending to follow the previously developed line, i.e., detect, through the testimonies of these teachers about what they think and how they say that they work, on factors that were linked to the causes and the consequences of a climate of malaise and wellbeing, while teachers, trying to contrast the different realities that we propose to investigate. The general Thematic Area was: causes and consequences of malaise and well-being in teachers, and used semi-structured interviews, using the technique of content analysis proposed by Bardin (2004).

\subsection{Results and Discussions of Qualitative Data}

The results so far show that are found coerenes with previous findings, as we describe below. Data from previous surveys of Stobäus \& Mosquera (2003), with emphasis on cotent analysis of the responses of the interviews proved to be similar to those found in the literature on the subject. Material resources, outdated, underutilized, outdated; difficulties in support for attendance at courses/conferences; working conditions: overload hours; difficulties in fulfilling various 
tasks; reaction to controls; dispersion in non-core activities; distinct evaluation processes (internal/external); requirements in the classroom, attending specificities/difficulties of students; institutional violence, veiled and symbolic, professionally/personally contend with his students/colleagues; teaching depletion and accumulation requirements: exhaustion, with psychosomatic manifestations; suggestions: the need to understand/clarify situations; further contact/academic and social activities with colleagues/supervisors, specific support via health professionals/Psychology.

Regarding the use of ICTs, we find similarities: instrumental use of Informational Technology (broad sense), but unaware of its potential application to the classroom and Education; Internet use/other tools for information, not so much in teaching; would like to receive continuing education and training; have students who use well, there are those who do not use computers, requiring digital literacy; discrepancies: some have computers, not others; some access network, Internet, Computer Labs, others not; in public school unless in private; the education and training of teachers is higher in individuals; satisfactions in using ICTs: fast access to information via the Internet, diversification of activities in class/aid in their preparation, the possibility of collaborative work with peers and between students; dissatisfactions in using ICTs: fear of replacement by the machine; little time for training/update; constraints: lack of control of the classroom; Forward-looking alternatives-use of three alternatives: prioritize their dedication, their innovative methodologies, and asking Training and update.

Data are in line with national and international findings. We seek to implement strategies forwarding the possibilities of well-being, as suggests de Jesus (1996, 1998a, 1998b, 2001), de Jesus et al. (2011), de Jesus, Vieira, Mosquera, Stobäus, \& Esteve (2004), Pereira, de Jesus, Esteve, Lens, Stobäus, \& Mosquera (2002), with proposals and results of Training Course for Promotion of Welfare, in addition to working with the theme of affectivity, and self-image and self-esteem of teachers proposed by Antunes, Stobäus, \& Mosquera (2008). The teacher must be aware of the need to better understand their reality, tending to the welfare and (self) personal and professional fulfillment.

In reference to some of the narratives, on material resources and working conditions, we highlight problems encountered in teaching with data in common, including the fact that there is a clear workload, either in direct relationship with the student, especially when they say "overloaded", is too demanding teacher "as well as the indirect work through statements like" too many students. We can also consider indirect overhead, with comments like "we have to control incoming and outgoing students, it takes time to make the call with so many students in room".

A very delicate point is precisely that appeared in the controls exercised by the university, appearing almost two angles, in which, on one hand, are arguments as "lacking control over those teachers who do not come to class or arrive late". In contrast, others say that "poor disclosure of criteria for evaluation and pro- 
motion", or "time is wasted in some detail and you cannot delve into important things".

Here it is worth noting the possibility of developing more self-image and self-esteem as real as possible, in order to face complex situations, highlighted by Lettnin, Dohms, Mendes, Stobäus, Mosquera, \& de Jesus (2015).

Also in relation to violence in schools, especially symbolic we note positions as "the need to make a clear assessment of the teacher, especially for promotion", "another situation that I perceive is competition, which is generally not veiled". Recall of symbolic violence, which is not always visible as well as the need to develop better levels of resilience and self care, as Timm, Stobäus, \& Mosquera $(2008,2010)$.

When commenting on the classroom specifically put that "I like to teach", "devote more time to some students for others", denoting inclusive posture, or stressing "P $m$ furious when not studying anything".

Already on teacher burnout and accumulation of demands on the teacher's demands appear, when they say "do not understand, ask yourself of everything yesterday, so it seems that they do not know how much it costs time to do", or "we produce, to send and sent in time to pay it out of our pocket".

Also clearly show the postures in relation to place greater emphasis on education, when they put that "I have to give good lessons well prepared", or "I disincentive to them, the ones who want nothing to do with anything, nor are your classes for the research that you talk about".

Commenting on learning, said that "they come with difficulties and I help them", or "I hate when they do not want to study, just sit in class and do not cooperate, those makes me ill, those who have difficulties I help".

Appeared several times in the matter of assessment, more in reference to what "the note can cause stress, there is competition", or "there are colleagues who pass the student for not bother, that 'explode' the thing after I had my discipline".

When asked about the institution and his colleagues appear more angles, such as "very good relationship with the teachers in the area, or know well the other". On $\mathrm{n}$ the other hand, commented "those conversations in the staff room when they speak evil of what is not there I do not like", or "we develop a project, think it s great, here comes and other cutting everything with one sentence", or "helping everyone alive, and had needed colleague and boss who refused to help".

When they speak of what could be done to minimize these stressors, from the outside in, commenting that "more meetings between colleagues maybe we know the most", or "lack much, the direction and the coordinators have to see all the possibilities that are all around us", denoting an idea of what the answers are external to the subject.

There are answers that demonstrate an inverse direction, from the inside out, "has a multiplicity of factors that make it all go, the teacher is the most important, also has the student understand the side teacher and he the student's side", or "when there is motivation on both sides and by the university, is good and walking forward". 
The proposals found by Sampaio, de Jesus, Mosquera, \& Stobäus (2009a, 2009b, 2009c) go in this direction.

We believe that here we could deepen with the idea that some people are more susceptible to feedback from other (outside), while others are less influenced, remembering the aspects emphasized by Mosquera (1983), in their studies of Adult Life and its implications educational as well as highlighting the dynamics of self-image and self-esteem, postulated by Lettnin, Dohms, Mendes, Stobaus, Mosquera, \& de Jesus (2015), towards better and more realistic personal and professional self-realization, by interinfluência between inside/outside, between what others say about us, what we hear and believe them to hear what we say and what they think of us, and really what we think of ourselves and influence ourselves.

Obviously, all this puts us in constant change between the internal and the external in the sense best chance of effective self-education, real healthy self-education, highlighting positive aspects as well in our personal/professional development, highlighted in Health Education as Mosquera \& Stobäus (1984).

In more recent work, Sampaio, de Jesus, Stobäus, \& Mosquera (2009a, 2009b, 2009c) and Stobäus, Mosquera, Timm, de Jesus, \& Sampaio (2010) found that, qualitatively and quantitatively, there are differences in some aspects of self-image, self-esteem and resilience when teachers undergo Continuing Education Program with teachers.

Also Timm, Mosquera, \& Stobäus $(2008,2010)$ highlight the need for greater caution if you, by the teacher, to ensure greater efficiency and effectiveness in personal and professional performances.

We realize that much of the information highlighted by respondents combined, broader or even specifically with the categorization found by Esteve (1984, 1994), in another cultural reality, but that, somehow, seems also to be implied or explicit in our research, and there are virtually no differences between these two groups.

We follow these still collecting data, conducting interviews and questionnaires applied for further analysis.

Another study was realized about the affectivity of teachers, highlighted in another article, by Dohms, Lettnin, Mendes, Mosquera, \& Stobäus (2014).

\subsection{Results and Discussions of Quantitative Data}

The Assessment Questionnaire of Teacher Malaise/Wellbeing of de Jesus (1998a), was used to inquiry the teachers about their malaise and well-being in some quantitative researchs of our group (Sampaio, de Jesus, Stobäus, \& Mosquera 2009a, 2009b, 2009c; Mendes \& Stobäus, 2012; Mendes, Zacharias, Mosquera, Stobäus, \& de Jesus, 2012).

In the book "Motivation for Teaching Profession. Contribution to the clarification of malaise situations and to the foundation of teacher training strategies", de Jesus (1996) used this instrument in the phase of its elaboration, in Portuguese teachers and potential teachers $(\mathrm{N}=143)$ of the final cycles of the Primary and secondary education, in Coimbra-PT. The training course for the preven- 
tion of malaise (de Jesus, 2007) takes place in 10 sessions ( 3 hours session), developing the following themes: professional project; Intrinsic motivation; Expectations of effectiveness, expectations of results control; Causal assignments, locus dimensions and stability, for successes and failures; Professional stress; Emotional exhaustion; Irrational beliefs; Coping strategies; Perception of professional success and subjective perception of professional well-being, with $26 \mathrm{sec}$ ondary school teachers. Some indicators were evaluated to compare the results in the initial and final phases, where it was found that there was a significant decrease in professional stress, irrational beliefs and an increase in motivation and subjective perception of professional well-being (de Jesus, 2007).

Using de Jesus' $(1996,1998$ a) researches as guiding principles of ours, we present some of them in Frame 1 below.

The study by Sampaio (2008) involved 15 teachers from the Basic Education of the Municipality of Ibema-PR, between April and December of 2006, with the completion of the 19 workshops of the Support Program for Teacher Welfare, and re-evaluation after two years.

A total of 30 teachers aged between 28 and 64 years ( $\mathrm{M}=48$ years) participated in the study, according to Mendes (2011), who answered the questionnaire for evaluation of teacher malice/well-being, and on average 12 years of work in the institution. The municipal school where these teachers worked is located in a peripheral district of the city of Porto Alegre, serving approximately 1300 students of Elementary and Young Adult Education, with a teaching staff of 96 teachers in 2010. The majority of the student is Low purchasing power. A psychopedagogical Workshop on Affectivity in Education was developed as a way to offer some subsidies on teacher welfare.

The research of Zacharias (2012) counted on 22 teachers, who were between 26 and 57 years old $(M=43$ years old), of three state schools, located in the central

Frame 1. Sinthesys of the programs/results of researches.

\begin{tabular}{|c|c|c|c|}
\hline Research & Sample & Aspects & Duration \\
\hline $\begin{array}{l}\text { Teaching wellbeing } \\
\text { support program } \\
\text { (Sampaio, 2008) }\end{array}$ & $\begin{array}{l}15 \text { teachers of Basic } \\
\text { Education in the } \\
\text { Municipality of } \\
\text { Ibema-PR }\end{array}$ & $\begin{array}{l}\text { Identification of the causes of teacher malaise; Identification of stress-generating } \\
\text { factors; Formulation of possible measures to be implemented for the balance } \\
\text { between private, professional, social, affective and health; Physical symptom } \\
\text { management skills; Cognition management skills; Teamwork skills; Affectivity } \\
\text { and assertiveness in Education; Competencies to manage situations of (in) } \\
\text { discipline of students in the classroom; spirituality; resilience; Coping strategies; } \\
\text { Health and quality of life of teachers. }\end{array}$ & $\begin{array}{c}19 \\
\text { Theoretical-practical } \\
\text { workshops } \\
\text { (50 hours) }\end{array}$ \\
\hline $\begin{array}{c}\text { Teacher } \\
\text { malaise/wellness }\end{array}$ & $\begin{array}{l}30 \text { teachers of the } \\
\text { Basic Education }\end{array}$ & & \\
\hline $\begin{array}{l}\text { assessment } \\
\text { questionnaire } \\
\text { (Mendes, 2011) }\end{array}$ & $\begin{array}{c}\text { Municipal Network } \\
\text { of Education of } \\
\text { Porto Alegre-RS }\end{array}$ & Psychopedagogical Workshop on Affectivity in Education. & 10 hours \\
\hline $\begin{array}{c}\text { assessment } \\
\text { questionnaire } \\
\text { (Zacharias, 2012) }\end{array}$ & $\begin{array}{c}\text { State System of } \\
\text { Education of Porto } \\
\text { Alegre-RS }\end{array}$ & Psychopedagogical workshop on student indiscipline and intervention measures. & 10 hours \\
\hline
\end{tabular}

Source: the authors. 
region of the city of Porto Alegre and work at Infant Education level and/or Elementary School. Having students of low social class, A psycho pedagogical workshop on student indiscipline and intervention measures was carried out with some of the teachers participating in the research.

In Table 1 is the results of the study by Sampaio, Stobäus, Mosquera, \& de Jesus (2012), with the 15 teachers of the Basic Education of the Municipality of Ibema-PR, regarding teacher malaria/welfare evaluation. There was a considerable reduction in the variables of professional stress and professional exhaustion, and improvement in coping strategies used. The results verified after a new collection, two years later, show maintenance of previous levels. From the results of this research, it should be pointed out that Programs such as this can help overcome and overcome malaise, leading to teacher well-being both personally and professionally.

Mendes (2011) and Zacharias (2012) used the Instrument for the Evaluation of Variables that constitute Indicators of Well-Being/Teacher Malaise (de Jesus, 1996), respectively, with 30 teachers in a municipal school and 22 teachers in three state schools, such as has already been quoted. Mendes, Zacharias, Mosquera, Stobäus, \& de Jesus (2012) elaborated a comparison of the means of some of the variables evaluated in the questionnaire, according to Table 2. The variables evaluation of the professional project, instrumental motivation and professional success are related to teacher well-being. The variables evaluation of professional stress and professional exhaustion are related to teacher malaise.

It is interpreted that the teacher who presents high means in the variables of Welfare and low means in the variables of malaise can present a greater professional well-being. If the opposite occurs, that is, low means in the welfare

Table 1. Averages obtained from variables of longitudinal evaluation of teachers' malaise/wellbeing (Sampaio, Stobäus, Mosquera, \& de Jesus, 2012).

\begin{tabular}{|c|c|c|c|c|c|c|c|c|}
\hline Variables & $\begin{array}{c}\text { M. } 1 \\
\text { Jul/2005 }\end{array}$ & $\begin{array}{c}\text { M. } 2 \\
\text { Dez/2005 }\end{array}$ & $\begin{array}{c}\text { M. } 3 \\
\text { Abr/2006 }\end{array}$ & $\begin{array}{c}\text { M. } 4 \\
\text { Dez/2006 }\end{array}$ & $\begin{array}{c}\text { M. } 5 \\
\text { Dez/2008 }\end{array}$ & $\begin{array}{c}\text { Average } \\
\text { diference } 1 \text { e } 2\end{array}$ & $\begin{array}{c}\text { Average } \\
\text { diference } 1 \text { e } 4\end{array}$ & $\begin{array}{c}\text { Average } \\
\text { diference } 4 \text { e } 5\end{array}$ \\
\hline Professional stress & 353.83 & 456.25 & 355.42 & 294.00 & 316.25 & $-102.42^{\star}$ & 59.83 & $-22.25^{\star}$ \\
\hline Professional exhaustion & 351.42 & 598.08 & 439.92 & 285.67 & 354 & $-246.67^{*}$ & 65.75 & $-68.33^{*}$ \\
\hline Coping strategies & 25.17 & 26.67 & 24.67 & 27.67 & 27 & -1.50 & $-2.50^{\star}$ & 0.67 \\
\hline
\end{tabular}

Source: Sampaio, Stobäus, Mosquera, \& de Jesus (2012). ${ }^{*} \mathrm{p}<0.05$.

Table 2. Averages of teacher's malaise/wellbeing variables in de Jesus (1998a), Mendes (2011) and Zacharias (2012).

\begin{tabular}{cccc}
\hline Variables & $\begin{array}{c}\text { de Jesus (1998a) } \\
\text { average }\end{array}$ & $\begin{array}{c}\text { Mendes (2011) } \\
\text { average }\end{array}$ & $\begin{array}{c}\text { Zacharias (2012) } \\
\text { average }\end{array}$ \\
\hline Professional project evaluation & 4.41 & 4.46 & 3.50 \\
Intrinsecal motivation evaluation & 22.46 & 24.33 & 20.63 \\
Professional success evaluation & 26.94 & 28.50 & 28.18 \\
Professional stress evaluation & 317.59 & 384.53 & 376.27 \\
Professional exhaustion evaluation & 428.78 & 607.33 & 591.31 \\
\hline
\end{tabular}

Source: Mendes, Zacharias, Mosquera, Stobäus, \& de Jesus (2012). 
variables and high means in the malaise variables, it is considered that the teacher is experiencing malaise in the profession.

In relation to the professional project, Portuguese and Brazilian teachers presented similar averages, although state teachers had a mean of $20.63 \%$ lower than those obtained by de Jesus (1998a), indicating a lesser purpose to follow in the teaching profession.

The evaluation of intrinsic motivation indicates the degree of motivation (satisfaction and achievement) of the teacher in his teaching activity, without the need for external reward. In this item, the groups obtained similar averages, although the Brazilian teachers of the municipal network expressed the highest averages.

The Brazilian teachers evaluated in a more positive way their professional success, regarding the accomplishment of the goals, than the Portuguese teachers.

It was verified that the Brazilian teachers had higher averages than the Portuguese in the evaluation of stress and professional exhaustion (Table 3). These results are related to the social issues of the Brazilian student. Students have a social condition in which they need support and help, social assistance and health, which are out of the reach of teachers and school, generating an overload and frustration that can turn into stress and exhaustion.

In this study (Mendes, 2011), we used inferential statistics, using the $t$ test, to verify if there was a significant difference between the averages of Portuguese and Brazilian teachers in relation to the variables already mentioned.

In the items of professional project evaluation, intrinsic motivation and professional exhaustion the $t$ test did not express significant differences between the means of the two groups of teachers.

In the professional stress variable, Brazilian teachers presented higher scores than the Portuguese. It is interpreted that Brazilians feel more affected by trying to motivate students who do not want to learn, by trying to control indiscipline in the classroom and often not succeeding.

The Brazilian teachers presented a significantly higher average than the Portuguese, in the variable professional success, which expresses a better perception of success in Brazilian teachers.

Table 3. Averages of teacher malaise/wellbeing variables of de Jesus (1996) and Mendes (2011).

\begin{tabular}{cccccc}
\hline Variables & $\begin{array}{c}\text { de Jesus (1996) } \\
\text { average, } \mathrm{N}=143\end{array}$ & $\begin{array}{c}\text { Standart } \\
\text { Deviation }\end{array}$ & $\begin{array}{c}\text { Mendes (2011) } \\
\text { average } \mathrm{N}=30\end{array}$ & $\begin{array}{c}\text { Standart } \\
\text { Deviation }\end{array}$ & $\begin{array}{c}\mathrm{t} \\
\text { value }\end{array}$ \\
\hline $\begin{array}{c}\text { Professional project evaluation } \\
\begin{array}{c}\text { Intrinsecal motivation } \\
\text { evaluation }\end{array}\end{array}$ & 4.41 & 1.66 & 4.46 & 1.54 & -0.15 \\
$\begin{array}{c}\text { Professional success evaluation } \\
\text { Professional stress evaluation }\end{array}$ & 22.46 & 3.71 & 24.33 & 6.50 & -1.52 \\
$\begin{array}{c}\text { Professional exhaustion } \\
\text { evaluation }\end{array}$ & 317.59 & 101.26 & 384.53 & 125.30 & -2.74 \\
\hline
\end{tabular}

Source: the authors. 


\section{Conclusion: And Now, What Can We Do?}

Clearly the actual and future "pictures" are not encouraging, and there is no ready-made recipes or some group dynamics can help to get the best of all worlds.

Can we react? We believe that we not only can, but must. We who chose teaching and we are in it with ease and interest, and we have to be realistic dialectically-futuristic-committed and hopeful and raise some possibilities for this.

\subsection{Teachers Training}

-Abandon normative approaches for training descriptive approaches; in other words, prepare for real and not make false ideals.

-Try to abandon the pedagogical ambiguity and give the teacher a part for innovative in knowledge.

-Adjust the initial contents of the reality for better initial teaching practice training.

-Emphasize the knowledge of cultural reality in this beginning of the new millennium to better suit the changing teaching profession.

Another point still stand that would fit in this lineup is just the preparation that teachers should have to deal with learning difficulties which may occur in the classroom and, even more, a whole specific preparation to stop "dealing" with people, especially with students with specific educational needs, towards a Health Education and Positive Psychology, preparing to better interpersonal relationships, and with affectivity, leading to develop life more positively, as previously highlighted.

\subsection{Professional Sense}

-Enhancing the teaching work by knowledge and competence. Teachers have to make a difference and thus we should be.

-Fighting for more social relevance: awareness of the real power of the teacher, as a citizen and as professional; study of the power of knowledge and cultural mediation.

-Consider the School and the University as radiators outbreaks of political education in the community, contributing to a substantial difference between the human and the possible and impossible human potential.

Our proposal is precisely to ongoing research, increasing the number of subjects, as well as researching another realities, including establishing and implementing most international exchange with researchers in order to contrast more data.

We conclude that the most important elements that have been pointed out and commented on in this article refer to the Theoretical Framework revised, revisiting classical authors in the area, and particularly the findings in our researches, both in Portugal and Brazil, which point to many similarities with findings of Literature. Also the proposal of some suggestions that could be taken into account in the continuing education and teachers education in different 
areas of activity, as well as managers of educational actions in the different education systems.

\section{References}

Abraham, A. et al. (1986). El enseñante es también una persona [The Teacher Is Also a Person]. Barcelona: Gedisa.

Antunes, D. D., Stobäus, C. D., \& Mosquera, J. J. M. (2008). Educação de jovens e adultos: relatos de professores e alunos e sua auto-imagem e euto-estima [Education of Youth and Adults: Reports of Teachers and Students and Their Self-Image and Euto-Esteem]. VII Seminário de Pesquisa em Educação da Região Sul-ANPEDSUL, Itajaí. http://www.portalanpedsul.com.br/admin/uploads/2008/Educacao_de_Jovens_e_Adult os/Trabalho/05_17_04_Educacao_de_Jovens_e_Adultos_Relatos_de_Professores_e_A luno.pdf

Bardin, L. (2004). Análise de Conteúdo [Content analysis] (3rd ed.). Lisboa: Edições 70.

de Jesus, S. N. (1996). A motivação para Profissão Docente. Contributo para a clarificação de situações de mal-estar e para a fundamentação de estratégias de formação de professores [Motivation for Teaching Profession. Contribution to the Clarification of Malaise Situations and to the Foundation of Teacher Training Strategies]. Aveiro: Estante editora.

de Jesus, S. N. (1997). Bem-estar dos professores. Estratégias para realização e desenvolvimento profissional [Teacher Welfare. Strategies for Professional Development and Development]. Coimbra: Edição do autor.

de Jesus, S. N. (1998a). Bem-estar dos professores [Teachers Welfare]. Porto: Porto Editora.

de Jesus, S. N. (1998b). Stress e estratégias de coping de médicos e professores [Stress and Coping Strategies of Doctors and Teachers]. Coimbra: Instituto de Clínica Geral.

de Jesus, S. N. (1999). Como prevenir e resolver o stress dos professores e a indisciplina dos alunos [How to Prevent and Solve Teacher Stress and Student Indiscipline]. Lisboa: ASA Editores.

de Jesus, S. N. (2001). Pistas para o bem-estar dos professores [Tracks for the welfare of teachers]. Educação-PUCRS, ano XXIV, 43, 123-132.

de Jesus, S. N. et al. (2011). Avaliação da motivação e do bem/mal-estar dos professores: Estudo comparativo entre Brasil e Portugal [Evaluation of Motivation and Well-Being/Malaise of Teachers: A Comparative Study between Brazil and Portugal]. Amazônica-Revista de Psicopedagogia, Psicologia Escolar e Educação, VII, 7-18.

de Jesus, S. N. et al. (2012). Impacto da formação sobre a motivação e o bem-estar: Estudos realizados com profesores em Portugal e no Brasil [Impact of Training on Motivation and Well-Being: Studies Carried out with Teachers in Portugal and Brazil]. In F. Rebelo, L. R. M, Teixeira, \& M. A. de S. Perrelli (Orgs.). Docência em questão: Discutindo trabalho e formação [Teaching in Question: Discussing Work and Training]. Campinas-SP: Mercado de Letras.

de Jesus, S. N., Vieira, J. C., Mosquera, J. J. M., Stobäus, C. D., \& Esteve, J. M. (2004). Formação em Gestão de Stresse [Stress Management Training]. Revista Mal Estar e Subjetividade, Fortaleza, 4, 358-371.

http://pepsic.bvsalud.org/scielo.php?script=sci_arttext\&pid=S1518-6148200400020001

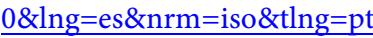

Dohms, K. P., da Conceição Lettnin, C., Mendes, A. R., Mosquera, J. J. M., \& Stobäus, C. D. (2014). Affectivity of University Teachers: Personal, Social and Institutional Aspects. Psychology, 15, 1783-1793. https://doi.org/10.4236/psych.2014.515185 
dos Santos, B. S., \& Boza Carreño, A. (2010). A Motivação em Diferentes Cenários [Motivation in Different Scenarios]. Porto Alegre: EdiPUCRS.

dos Santos, B. S., Stobäus, C. D., Mosquera, J. J., \& Missel, F. de A. (2005). O Mal-Estar Docente perante o uso das Tecnologias de Informação e Comunicação [Teaching Malaise Regarding the Use of Information and Communication Technologies]. REICE, Barcelona, 3, 344-358. http://www.redalyc.org/pdf/551/55130135.pdf

Esteve, J. M. (1984). Profesores en conflicto [Teachers in Conflict]. Madrid: Narcea.

Esteve, J. M. (1994). El malestar docente [Teacher Discomfort]. (13th ed.). Barcelona: Paidós.

Esteve, J. M. (2005). Bem-estar e saúde docente [Wellness and Teaching Health]. Revista PRELAC-Educação para todos. Escritório Regional de Educação da UNESCO para a América Latina e o Caribe. OREALC/UNESCO, Santiago-Chile, 1 (Ano I), 116-133. http://unesdoc.unesco.org/images/0014/001446/144666por.pdf

Freire, P. (1979). Educação e mudança [Education and Change] (12th ed.). Rio de Janeiro: Paz e Terra.

Lettnin, C., Dohms, K., Mendes, A., Stobaus, C., Mosquera, J., \& de Jesus, S. (2015). Evaluating Self-Esteem Levels of Brazilian and Portuguese Adolescents. Psychology, 6, 314-322. http://file.scirp.org/Html/2-6901362_54363.htm https://doi.org/10.4236/psych.2015.64032

Mendes, A. R. (2011). Saúde docente: Uma realidade detectada-Em direção ao bemestar e a realização profissional [Teaching Health: A Reality Detected-Toward WellBeing and Professional Achievement]. Dissertação (Mestrado em Educação)-Faculdade de Educação, Pontifícia Universidade Católica do Rio Grande do Sul, Porto Alegre.

http://repositorio.pucrs.br/dspace/bitstream/10923/2721/1/000437482-Texto\%2BComp leto-0.pdf

Mendes, A. R., Zacharias, J., Mosquera, Stobaus, C. D., \& de Jesus, S. N. (2012). $\mathrm{Mal} / \mathrm{bem}$-estar docente em escolas públicas de Porto Alegre [Teacher Malaise/Welfare in Public Schools in Porto Alegre]. In M. G. Tommasiello, A. J. Marin, S. G. Pimenta, L. M. Carvalho, \& J. C. Fusali (Org.), Didática e práticas de ensino na realidade escolar contemporânea: Constatações, análises e proposições [Didactics and Teaching Practices in Contemporary School Reality: Findings, Analyzes and Propositions] (Vol. 2, pp. 002995-003007). Araraquara, SP: Junqueira \& Marin Editores.

http://www.infoteca.inf.br/endipe/smarty/templates/arquivos_template/upload_arquiv os/acervo/docs/2431c.pdf

Mosquera, J. J. M. (1978). O professor como pessoa [The Teacher as a Person]. Porto Alegre: Sulina.

Mosquera, J. J. M. (1983). Vida Adulta [Adulthood] (2nd ed.). Porto Alegre: Sulina.

Mosquera, J. J. M., \& Stobäus, C. D. (1984). Educação para a Saúde [Health Education] (2nd ed.). Porto Alegre: D.C. Luzzatto.

Mosquera, J. J. M., \& Stobäus, C. D. (2003). O mal-estar na docência: Causas e conseqüências. Relatório de Pesquisa [Malaise in Teaching: Causes and Consequences. Research Report]. Porto Alegre: Faculdade de Educação-PUCRS.

Mosquera, J. J. M., \& Stobäus, C. D. (2006). Afetividade: Manifestação de sentimentos e Educação. Educação-PUCRS, Porto Alegre, 58, 123-133.

http://revistaseletronicas.pucrs.br/ojs/index.php/faced/article/viewFile/438/334

Mosquera, J. J. M., Stobäus, C. D., \& Huertas, J. A. (2015). Teachers in Post-Modern Era: Narratives of Teaching Subjectivity. Creative Education, 6, 945-952.

http://file.scirp.org/Html/5-6302573_57271.htm 
Mosquera, J. J. M., Stobäus, C. D., \& Timm, E. Z. (2009). O professor e o cuidado de si: Perspectivando a própria vida como uma obra de arte. Por que não? [The Teacher and the Care of Him/Herself: Looking at Life Itself as a Work of Art. Why Not?]. Ciência em Movimento, Porto Alegre, 22, 47-53.

https://www.metodista.br/revistas/revistas-ipa/index.php/EDH/article/viewFile/115/80 https://doi.org/10.15602/1983-9480/cmedh.v11n22p47-53

Pereira, A., de Jesus, S. N., Esteve, J. M., Lens, W., Mosquera, J. J. M., \& Stobäus, C. D. (2002). Teachers Wellbeing by a Training Program: A Longitudinal Approach. The 16th Conference of the European Health Psychology Society, Lisboa, 2-5 October 2002, 413-420. http://www.isabel-leal.com/portals/1/pdfs/16\%20congresso.pdf

Sampaio, A. A. (2008). Programa de Apoio ao Bem-estar Docente: Construção profissional e cuidar de si [Teaching Wellbeing Support Program: Professional Construction and Caring for Him/herself]. Dissertação (Mestrado em Educação), Porto Alegre: Faculdade de Educação da PUCRS.

http://repositorio.pucrs.br/dspace/bitstream/10923/2913/1/000404978-Texto\%2BComp leto-0.pdf

Sampaio, A., de Jesus, S. N., Stobäus, C. D., \& Mosquera, J. J. M. (2009a). Implementação de bem-estar profissional e pessoal através de programa de apoio ao bem-estar docente [Implementation of Professional and Personal Well-Being through a Teacher Welfare Support Program]. In I Congresso Luso-Brasileiro de Psicologia da Saúde, Resumos e Textos do Congresso Luso-Brasileiro de Psicologia da Saúde (pp. 774-786). FaroPortugal: Centro Universitário de Investigação em Psicologia-CIUP, Universidade do Algarve.

Sampaio, A., de Jesus, S. N., Stobäus, C. D., \& Mosquera, J. J. M. (2009b). Resultados qualitativos do Programa de Apoio Docente [Qualitative Results of the Teaching Support Program]. In I Congresso Luso-Brasileiro de Psicologia da Saúde, Faro-PT, Resumos e Textos do Congresso Luso-Brasileiro de Psicologia da Saúde (pp. 787-802). Faro-Portugal: Centro universitário de Investigação em Psicologia-CIUP, Universidade do Algarve.

Sampaio, A., de Jesus, S. N., Stobäus, C. D., \& Mosquera, J. J. M. (2009c). Programa de Apoio ao Bem-estar Docente: resultados quantitativos passados dois anos de seu desenvolvimento [Teaching Welfare Support Program: Quantitative Results after Two Years of Its Development]. In II Seminário Nacional de Educação, XIII Semana de Pedagogia: Conhecimentos, (Re)contruçôes e Práticas Pedagógicas (pp. 1-11). Universidade Estadual do Oeste do Paraná, Fransisco Beltrão.

Sampaio, A., Stobäus, C. D. Mosquera, J. J. M., \& de Jesus, S. N. (2012). Efeitos de um programa de apoio ao bem-estar docente na construção pessoal e profissional [Effects of a Teacher Welfare Program on Personal and Professional Construction]. IX Seminário de Pesquisa em Educação da Região Sul-ANPEDSUL, Caxias do Sul-RS. http://www.ucs.br/etc/conferencias/index.php/anpedsul/9anpedsul/paper/viewFile/721 1373

Sousa, C. (2006). Educação para a resiliência [Education for Resilience]. Tavira, PT: Município de Tavira.

Stobäus, C. D., \& Mosquera, J. J. M. (2005). Ideários da Educação Especial através de depoimentos de professores e seus alunos. In D. Rodrigues, R. Krebs, \& S. N. Freitas (Org.), Educação Inclusiva e Necessidades Educacionais Especiais [Inclusive Education and Special Educational Needs] (pp. 113-133). Santa Maria: Editora UFSM.

Stobäus, C. D., \& Mosquera, J. J. M. (2014). Positive Psychology and Emotional Schedule: Building Healthy Self-Construction. Psychology, 5, 533-540. https://doi.org/10.4236/psych.2014.56063

Stobäus, C. D., \& Mosquera, J. J. M. (Org.) (2012). Educação Especial: Em direção à 
Educação Inclusiva [Special Education: Towards Inclusive Education] (4th ed.). Rev. amp. Porto Alegre: EdiPUCRS.

Stobäus, C. D., Mosquera, J. J. M., \& dos Santos, B. S. (2007). Grupo de Pesquisa mal-estar e bem-estar na docência. Educação-PUCRS, ano XXX, 259-272. http://revistaseletronicas.pucrs.br/ojs/index.php/faced/article/viewFile/3562/2787

Stobäus, C. D., Mosquera, J. J. M., Timm, E. Z., de Jesus, S. N., \& Sampaio, A. (2010). Rumo ao bem-estar docente. In: VIII Encontro de Pesquisa em Educação da Região Sul-ANPED-SUL, Londrina-PR (pp. 1-17). Londrina, PR: Universidade Estadual de Londrina.

http://www.portalanpedsul.com.br/2010/?link=eixos\&acao=buscar_trabalhos

Teixeira, T. C., Mosquera, J. J. M., \& Stobäus, C. D. (2015). Teachers Tell Us about Full Inclusion. Creative Education, 6, 1044-1052.

http://file.scirp.org/Html/12-6302464_57393.htm

https://doi.org/10.4236/ce.2015.610103

Timm, E. Z., Mosquera, J. J. M., \& Stobäus, C. D. (2008). Resiliência: Necessidade e possibilidade de problematização em contextos de docência. Educação-PUCRS, Porto Alegre, 31, 39-45.

http://revistaseletronicas.pucrs.br/ojs/index.php/faced/article/viewFile/2755/2103

Timm, E. Z., Mosquera, J. J. M., \& Stobäus, C. D. (2010). O mal-estar na docência em tempos líquidos de modernidade. Revista Mal-Estar e Subjetividade, Fortaleza-CE, 10. http://pepsic.bvsalud.org/scielo.php?pid=S1518-61482010000300008\&script=sci_arttex $\underline{\mathrm{t}}$

Weber, S. W., Mosquera, J. J. M., \& Stobäus, C. D. (2009). O trabalho coletivo, cooperativo e solidário em educação a distância: desencadeador do bem-estar docente na educação superior. Diálogo, Canoas, 15, 123-139.

http://revistas.unilasalle.edu.br/index.php/Dialogo/article/viewFile/179/193

Zacharias, J. (2012). Bem-estar docente: Um estudo em escolas públicas de Porto Alegre [Teacher Welfare: A Study in Public Schools in Porto Alegre]. Dissertação (Mestrado em Educação), Porto Alegre: Faculdade de Educação, Pontifícia Universidade Católica do Rio Grande do Sul.

http://repositorio.pucrs.br/dspace/bitstream/10923/2874/1/000437549-Texto\%2BComp leto-0.pdf

\section{Submit or recommend next manuscript to SCIRP and we will provide best service for you:}

Accepting pre-submission inquiries through Email, Facebook, LinkedIn, Twitter, etc. A wide selection of journals (inclusive of 9 subjects, more than 200 journals)

Providing 24-hour high-quality service

User-friendly online submission system

Fair and swift peer-review system

Efficient typesetting and proofreading procedure

Display of the result of downloads and visits, as well as the number of cited articles

Maximum dissemination of your research work

Submit your manuscript at: http://papersubmission.scirp.org/

Or contact ce@scirp.org 